\title{
Parenting daughters does not increase monetary prosocial behavior: evidence from the Dictator Game
}

\author{
Johannes Leder ${ }^{1, \dagger}$, Paweł Niszczota ${ }^{2, \dagger, *}$ \\ Accepted for publication in Social Psychology
}

${ }^{1}$ University of Bamberg, Institute of Psychology, Bamberg, Germany

${ }^{2}$ Poznań University of Economics and Business, Humans and Artificial Intelligence Laboratory (HAI Lab), Institute of International Business and Economics, Poznań, Poland

${ }^{\dagger}$ These authors contributed equally to this work.

* Corresponding author: Paweł Niszczota, Poznań University of Economics and Business, al. Niepodległości 10, 61-875, Poznań, Poland; pawel.niszczota@ue.poznan.pl;

ORCID: 0000-0002-4150-3646

\section{Data availability}

Data can be accessed from the German Socio-Economic Panel (SOEP) upon request (https://www.diw.de/en/diw 01.c.601584.en/data_access.html). The $R$-code is deposited at https://osf.io/5hst3.

Declarations of interest: none.

Funding: This research did not receive any specific grant from funding agencies in the public, commercial, or not-for-profit sectors.

\section{Author contributions}

Both authors were involved in all parts of the research.

Wordcount: 3,785

\begin{abstract}
Prior work suggests that parenting daughters makes the preferences of men more in line with those of women. We use behavior in a Dictator Game as a measure of pure social preferences, to test whether parenting daughters increases prosociality, specifically charitable giving. Data is sourced from the German Socio-Economic Panel, where 1,461 participants decided how to split a $50 €$ endowment between themselves and (separately) a needing domestic or foreign recipient. Our results suggest that parenting daughters does not make men (nor women) more prosocial. The findings remain null across different operationalizations and analytical procedures.
\end{abstract}

Keywords: Daughters; Dictator Game; Prosocial Behavior; Charitable Behavior; Preferences 


\section{Introduction}

A growing number of studies investigate how parenting daughters affects judgments and decisions (e.g., Calder-Wang \& Gompers, 2021; Cronqvist \& Yu, 2017; Van Effenterre, 2020; Warner, 1991; Washington, 2008). A recurring finding is that having daughters makes men more sympathetic towards women's rights and opportunities. For example, it shows that parenting daughters affects congressional votes concerning women's rights issues (Washington, 2008), and increases the likelihood of female partners being employed in venture capital funds (Calder-Wang $\&$ Gompers, 2021). The findings of one study even suggest that such "daughter effects" might extend to social behavior: Cronqvist and $\mathrm{Yu}$ (2017) show that firms that are helmed by CEOs with daughters are more likely to engage in corporate social responsibility policies. While early research suggested that this tendency is egoistic from the father's perspective (Warner, 1991), later research proposes that having daughters makes males more prosocial (Cronqvist \& Yu, 2017). The latter, however, confounds social preferences with egoistic motives, as corporate social responsibility or women's rights makes the world more favorable for people like the daughter. In this case, prosocial behavior has an indirect personal consequence. In this study, we use responses in a Dictator Game as a "pure" measure of prosocial behavior to delineate the egoistic daughter effect from the prosocial daughter effect. Responses in such games are unaffected by fear of retaliation, and egoistic and prosocial motives have clear distinct behavioral responses, allowing us to extract the effect of parenting daughters on social preferences.

In the present study, we test the hypothesis that parenting daughters results in social preferences that reflects higher prosocial motivation in males. If we refute the hypothesis this would suggest that in previous research, prosocial behavior could be explained by egoistic motives. On the other hand, if confirmed, it would suggest that males parenting daughters indeed become more prosocial.

To find higher prosocial behavior in the Dictator Game of males with daughters would be in line with the female socialization hypothesis (Cronqvist \& Yu, 2017), based on which one can assume that parenting daughters will make the social preferences of men more in line with those of women. Overall, women tend to exhibit more prosocial behavior, which is also evident in behavior in the Dictator Game studies (e.g., Achtziger et al., 2015). A recent meta-analysis by Bilén et al. (2020) estimates that women give $\sim 4$ percentage points more to recipients than men do (which corresponds to a $d=0.16$ effect). The finding of women being more prosocial in this paradigm is corroborated in other research. Consistent with this finding, we hypothesize that people with daughters will give more in a Dictator Game, an effect that should be more pronounced in men.

\section{Method}

\subsection{Sample and Design}

To test the presence of a "daughter effect", we used data from the German Socio-Economic Panel (SOEP)-Innovation Sample study of 2017 (Goebel et al., 2018). SOEP is a long-running household panel study that provides a representative view of the structure and traits of the entire population living in Germany (Wagner et al., 2007; see Dittrich and Mey (2021) for an alternative study on charitable behavior that uses data from this dataset).

We used data of $N=1,461$ (female $\left.=55.1 \%, M_{\text {age }}=54.02, S D=18.84\right)$ respondents who responded to the donation questions (see Electronic Supplementary Material 1). In the donation 
question, subjects answered two questions (how much of $50 €$ to donate to a domestic family and how much to keep, and how much of $50 €$ to donate to a foreign family and how much to keep), and subjects knew that $1 / 7$ of subjects will be selected and paid for one of the two tasks. Thus, each task had a 1/14 chance of being implemented. The decisions, therefore, were about real monetary payoffs. Participants' information concerning the number, age, and gender of their children (or lack of children) was provided in the SOEP dataset. We used the entire adult population that met this criterion (details on all demographic variables are in Electronic Supplementary Material 1 Table S1).

A simulation-based sensitivity analysis showed that our design - controlling for age, number of children, income, education, and marital status - had sufficient statistical power of $1-\beta=80 \%$ to detect an effect size of $r=.14$ for the effect of the number of daughters and being male. This corresponds to $1.92 \%$ variance explained (given the covariates). To identify the probability that a significant finding is a true positive given our study design, we also estimated the positive predictive values for different simulated true effect sizes (Ioannidis, 2005). Under the assumption of equal prior probabilities for $H 0$ and $H 1$, the positive predictive value was above $80 \%$ for an effect size of $r=.05$ (around $0.25 \%$ variance explained). The plot of the power and predictive value curves is shown in Electronic Supplementary Material 1 Figure S1.

\subsection{Analytical approach}

To test the hypotheses, we built a series of mixed-model regressions that closely resembled those conducted in prior work on the daughter effect (Washington, 2008). A key feature of these regressions is that they estimate the incremental effect of parenting daughters, controlling for the number of children. Our first model extended the model proposed by Washington (2008) by additionally modeling the possible effect of the donation target - which was either a domestic or a foreign family. Model 1 was specified as:

$$
\begin{gathered}
Y_{i}=\alpha+\beta_{1} \text { Num.daughters }+\beta_{2} \text { foreignDonation }+\beta_{3} \text { Num.children } \\
+\beta_{4} \text { Num.daughters } * \text { foreignDonation }+\varepsilon_{i}
\end{gathered}
$$

The dependent variable $\left(Y_{i}\right)$ in this model is the amount donated to either a German family in need (i.e., people from the survey participants' country of residence), or a family from Kenya or Uganda (an outgroup, but for whom the donation would be more beneficial). In this model, the key parameter is $\beta_{1}$, which shows the effect of each additional parented daughter across participants (when the domestic family is the recipient; $\beta_{4}$ tests whether the effect of parenting daughters is different when the target family is foreign).

Surprisingly, arguably the most influential research on the daughter effect (Cronqvist \& Yu, 2017; Washington, 2008) rarely tests whether the effect of parenting daughters is different across men and women, even though the dominant explanation for it is female socialization. It is evident that if this was the case, then the daughter effect should be stronger in men (who benefit more from parenting a female) than in women (who are already female). Thus, it is important to test for differences across male and female parents, which we do via Model 2:

$$
\begin{gathered}
Y_{i}=\alpha+\beta_{1} \text { Num.daughters }+\beta_{2} \text { foreignDonation }+\beta_{3} \text { Num. children }+ \\
\beta_{4} \text { Num.daughters } \times \text { foreignDonation }+\beta_{5} \text { female }+\beta_{6} \text { Num. daugthers } \times \\
\text { female }+\beta_{7} \text { female } \times \text { foreignDonation }+\beta_{8} \text { Num. daugthers } \times \text { female } \times \\
\text { foreignDonation }+\varepsilon_{i}
\end{gathered}
$$


In this regression, $\beta_{1}$ shows the effect of each additional parented daughter for men, and $\beta_{6}$ shows how parenting daughters differs across women and men. The difference in the effect of daughters for females when donating to a foreign family is captured in the parameter for the three-way interaction, $\beta_{8}$.

Finally, we present two further models, that extend Model 2 by including controls. Note that we decided to present two models because information about religion was only available for 558 participants. Model 3 controls for marital status, household income, years of education, and age:

$$
\begin{aligned}
Y_{i}=\alpha+\beta_{1} \text { Num.daughters }+\beta_{2} \text { foreignDonation }+\beta_{3} \text { Num. children } \\
\\
+\beta_{4} \text { Num.daughters } \times \text { foreignDonation }+\beta_{5} \text { female } \\
+\beta_{6} \text { Num.daugthers } \times \text { female }+\beta_{7} \text { female } \times \text { foreignDonation } \\
+\beta_{8} \text { Num.daugthers } \times \text { female } \times \text { foreignDonation }+\beta_{9} \text { married } \\
+\beta_{10} \text { LogIncome }+\beta_{11} \text { education }+\beta_{12} \text { age }+\varepsilon_{i}
\end{aligned}
$$

Model 4 extends Model 3 with the addition of indicator variables corresponding to the religion of the participant:

$$
\begin{aligned}
Y_{i}=\alpha+\beta_{1} \text { Num.daughters }+\beta_{2} \text { foreignDonation }+\beta_{3} \text { Num. children } \\
\\
+\beta_{4} \text { Num. daughters } \times \text { foreignDonation }+\beta_{5} \text { female } \\
+\beta_{6} \text { Num.daugthers } \times \text { female }+\beta_{7} \text { female } \times \text { foreignDonation } \\
+\beta_{8} \text { Num. daugthers } \times \text { female } \times \text { foreignDonation }+\beta_{9} \text { married } \\
+\beta_{10} \text { LogIncome }+\beta_{11} \text { education }+\beta_{12} \text { age }+\beta_{13} \text { ReligionCatholic } \\
+\beta_{14} \text { ReligionProtestant }+\beta_{15} \text { ReligionOther }+\varepsilon_{i}
\end{aligned}
$$

We made two deviations from the pre-registered analysis. First, we focused solely on biological children, due to a large number of missing or inconsistent data on the total number of children in the household (which resulted in a lower quality of data on non-biological children). Our approach was validated by SOEP. Second, we included the target families' country of origin as a fixed effect in the interaction related to having daughters, as it is a relevant factor in the experimental design and accounts for substantial variance in the responses. We discovered this after data inspection and a comparison of models with and without the fixed effect of country. This is supported by a test of deviance $s$ for Model 1, $\chi^{2}(2)=159.95, p<.001$, and Model 2, $\chi^{2}(4)=$ $161.87, p<.001$. However, in Electronic Supplementary Material 1 we also present regressions that are specified in the pre-registration.

The study was preregistered at https://aspredicted.org/nm9st.pdf. Data was gathered as part of the Innovation Sample Wave of 2017. The preregistration was completed after data acquisition by the SOEP but before data was acquired from the SOEP by the authors. No analyses were performed before the pre-registration. The R-code is deposited at https://osf.io/5hst3.

\section{Results}

Participants gave on average $28.0 €(95 \% C I[27.3,28.8])$ to a domestic family, and $31.8 €(95 \%$ $C I=[31.0,32.6])$ to a foreign family $(d=0.24,95 \% C I[0.17,0.32])$. Male respondents $(28.6 €$, $95 \% C I[27.8,29.5])$ gave less than female respondents did $(31.0 €, 95 \% C I[30.2,31.7] ; d=-0.15$, $95 \%$ CI $[-0.22,-0.08])$. The donations depending on the number of daughters are shown in Fig. 1 . 


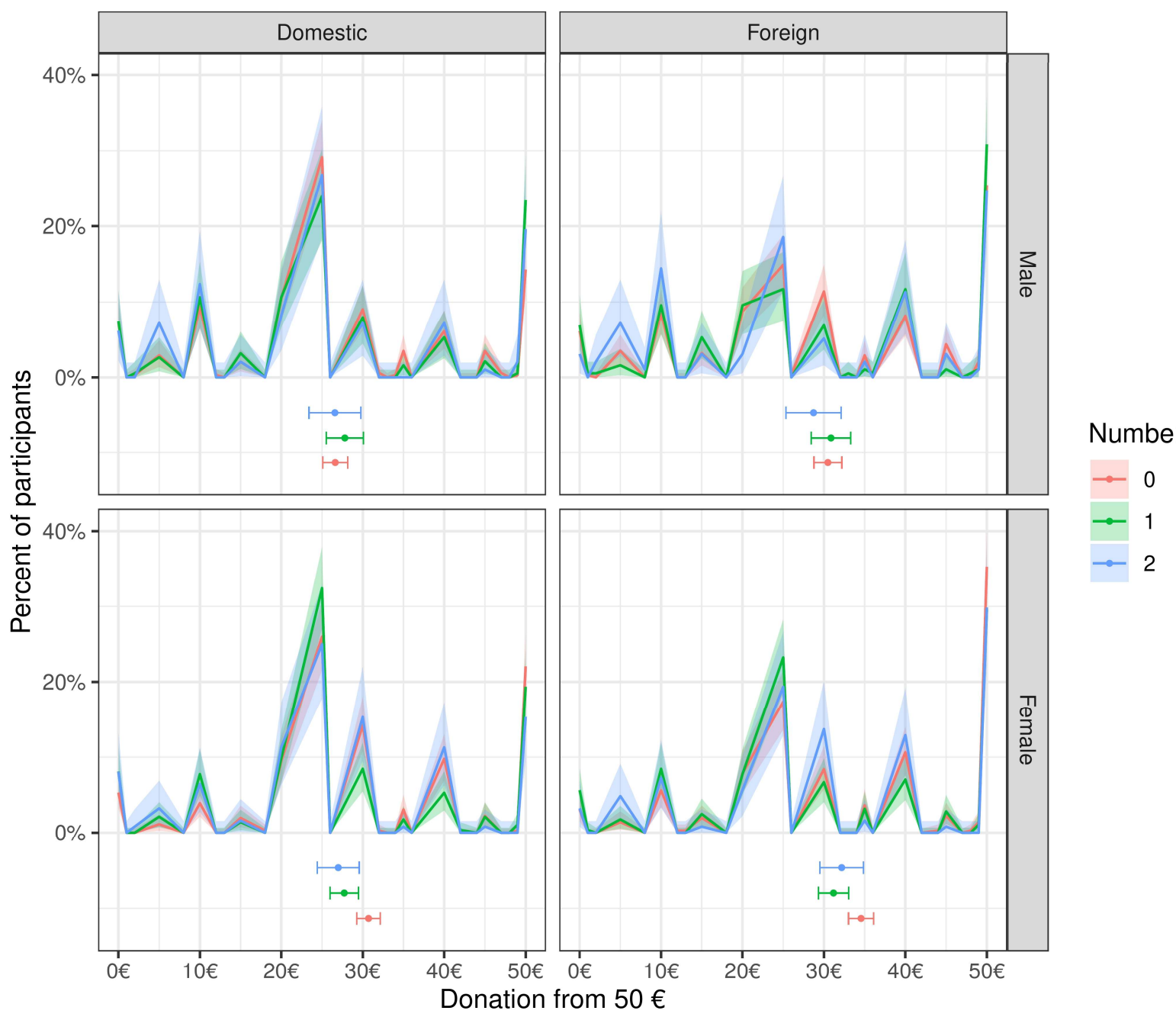

Fig. 1. Donations and degree of generosity depending on the origin of the recipient, number of daughters, and respondent's sex.

Notes: Lines represent the proportion of respondents making donations, which are in the $0-50 €$ range. The ribbon shows the $95 \%$ CIs for the proportion. The point and error bar below each plot shows the mean donation and its $95 \%$ CI for each number of daughters, grouped by respondent's sex and the origin of the recipient. We only plotted data for respondents with up to two daughters, as the number of participants with more daughters was small, which resulted in a high variance. A plot with up to three daughters can be found in Electronic Supplementary Material 1. 
As preregistered, we tested the four linear models predicting donation behavior and did not find an effect of daughters on the donation behavior of male (or female) respondents. Following the specification of Washington (2008), the main effect of daughters in Model 1 shows the effect of daughters without accounting for the respondents being male or female. The effect of daughters was small and not significantly different from zero, $b_{1}$ unstandardized $=0.23,95 \% C I[-$ $1.02,1.48], b_{1 \_ \text {standardized }}=0.01,95 \% C I[-0.06,0.09], p=.72$. We used Model 2 to test the effect of daughters for males, in which the main effect of daughters $\beta_{1}$ captures the effect of daughters for male participants. Results of the linear regression show that daughters had a nonsignificant positive effect on donations of male participants, $b_{1}$ unstandardized $=1.08,95 \% C I$ $[-0.53,2.70], b_{1}$ standardized $=0.06,95 \% C I[-0.03,0.16], p=.19$. The target family's country of origin $\left(\beta_{4}\right)$ or being female $\left(\beta_{6}\right)$ did not significantly affect the slope of the effect of having daughters, nor was there a Number of daughters $\times$ Female participant $\times$ Foreign donation $\left(\beta_{8}\right)$ interaction. Key findings held in Models 3-4, which included controls (see Table 1).

Table 1. Results of Linear Regression Models Predicting Donations.

\begin{tabular}{|c|c|c|c|c|c|}
\hline $\boldsymbol{\beta}$ & Variable & Model 1 & Model 2 & Model 3 & Model 4 \\
\hline- & Intercept & $\begin{array}{c}-0.12 * * * \\
{[-0.17,-0.07]}\end{array}$ & $\begin{array}{c}-0.20 * * * \\
{[-0.28,-0.12]}\end{array}$ & $\begin{array}{c}-0.20 * * * \\
{[-0.28,-0.13]}\end{array}$ & $\begin{array}{c}-0.19 * * * \\
{[-0.36,-0.02]}\end{array}$ \\
\hline 1 & Number of daughters & $\begin{array}{c}0.01 \\
{[-0.06,0.09]}\end{array}$ & $\begin{array}{c}0.06 \\
{[-0.03,0.16]}\end{array}$ & $\begin{array}{c}0.01 \\
{[-0.08,0.11]}\end{array}$ & $\begin{array}{c}-0.02 \\
{[-0.18,0.14]}\end{array}$ \\
\hline 2 & Foreign donation & $\begin{array}{c}0.24 * * * \\
{[0.21,0.28]}\end{array}$ & $\begin{array}{c}0.22 * * * \\
{[0.17,0.28]}\end{array}$ & $\begin{array}{c}0.21 * * * \\
{[0.15,0.26]}\end{array}$ & $\begin{array}{c}0.27 * * * \\
{[0.18,0.35]}\end{array}$ \\
\hline 3 & Number of children & $\begin{array}{c}-0.07 * \\
{[-0.14,-0.00]}\end{array}$ & $\begin{array}{c}-0.08 * \\
{[-0.15,-0.01]}\end{array}$ & $\begin{array}{c}-0.04 \\
{[-0.11,0.03]}\end{array}$ & $\begin{array}{c}0.02 \\
{[-0.10,0.14]}\end{array}$ \\
\hline 4 & $\begin{array}{l}\text { Number of daughters } \times \text { Foreign } \\
\text { donation }\end{array}$ & $\begin{array}{c}0.01 \\
{[-0.03,0.05]}\end{array}$ & $\begin{array}{c}-0.02 \\
{[-0.07,0.04]}\end{array}$ & $\begin{array}{c}-0.01 \\
{[-0.07,0.05]}\end{array}$ & $\begin{array}{c}0.00 \\
{[-0.09,0.10]}\end{array}$ \\
\hline 5 & Female participant & & $\begin{array}{c}0.15^{* *} \\
{[0.04,0.25]}\end{array}$ & $\begin{array}{c}0.16^{* *} \\
{[0.06,0.27]}\end{array}$ & $\begin{array}{c}0.29 * * \\
{[0.13,0.46]}\end{array}$ \\
\hline 6 & $\begin{array}{l}\text { Number of daughters } \times \text { Female } \\
\text { participant }\end{array}$ & & $\begin{array}{c}-0.08 \\
{[-0.18,0.02]}\end{array}$ & $\begin{array}{c}-0.02 \\
{[-0.12,0.08]}\end{array}$ & $\begin{array}{c}-0.01 \\
{[-0.18,0.16]}\end{array}$ \\
\hline 7 & $\begin{array}{l}\text { Female participant } \times \text { Foreign } \\
\text { donation }\end{array}$ & & $\begin{array}{c}0.03 \\
{[-0.04,0.11]}\end{array}$ & $\begin{array}{c}0.04 \\
{[-0.04,0.11]}\end{array}$ & $\begin{array}{c}-0.01 \\
{[-0.12,0.11]}\end{array}$ \\
\hline 8 & $\begin{array}{l}\text { Number of daughters } \times \text { Female } \\
\text { participant } \times \text { Foreign donation }\end{array}$ & & $\begin{array}{c}0.04 \\
{[-0.03,0.11]}\end{array}$ & $\begin{array}{c}0.05 \\
{[-0.03,0.12]}\end{array}$ & $\begin{array}{c}-0.00 \\
{[-0.12,0.12]}\end{array}$ \\
\hline 9 & Married & & & $\begin{array}{c}-0.08 * * \\
{[-0.13,-0.02]}\end{array}$ & $\begin{array}{c}-0.08 \\
{[-0.16,0.01]}\end{array}$ \\
\hline 10 & Log income & & & $\begin{array}{c}0.20^{* *} \\
{[0.15,0.26]}\end{array}$ & $\begin{array}{c}0.16^{* *} \\
{[0.07,0.24]}\end{array}$ \\
\hline 11 & Education & & & $\begin{array}{c}0.17 * * \\
{[0.12,0.23]}\end{array}$ & $\begin{array}{c}0.23 * * \\
{[0.14,0.31]}\end{array}$ \\
\hline
\end{tabular}




\begin{tabular}{|c|c|c|c|c|c|}
\hline$\beta$ & Variable & Model 1 & Model 2 & Model 3 & Model 4 \\
\hline 12 & Age & & & $\begin{array}{c}-0.02 \\
{[-0.07,0.03]}\end{array}$ & $\begin{array}{c}-0.03 \\
{[-0.11,0.06]}\end{array}$ \\
\hline 13 & Religion $=$ Catholic & & & & $\begin{array}{c}-0.14 \\
{[-0.38,0.10]}\end{array}$ \\
\hline 14 & Religion $=$ Protestant & & & & $\begin{array}{c}-0.12 \\
{[-0.30,0.07]}\end{array}$ \\
\hline 15 & Religion $=$ Other & & & & $\begin{array}{c}-0.19 \\
{[-0.39,0.01]}\end{array}$ \\
\hline & $\sigma 2$ & 61.47 & 61.47 & 60.67 & 56.2 \\
\hline & $\tau 00$ & 174.27 pid & 172.74 pid & $151.82 \mathrm{pid}$ & $157.62 \mathrm{pid}$ \\
\hline & ICC & 0.74 & 0.74 & 0.71 & 0.74 \\
\hline & $\mathrm{N}$ & 1460 pid & 1460 pid & 1368 pid & 559 pid \\
\hline & Observations & 2918 & 2918 & 2734 & 1116 \\
\hline & Marginal $\mathrm{R}^{2}$ / Conditional $\mathrm{R}^{2}$ & $0.018 / 0.744$ & $0.026 / 0.744$ & $0.111 / 0.746$ & $0.135 / 0.773$ \\
\hline & Deviance & 23063.18 & 23048.35 & 21421.20 & 8701.79 \\
\hline & AICc & 23078.09 & 23066.82 & 21451.29 & 8718.48 \\
\hline & log-Likelihood & -11532.02 & -11522.37 & -10710.56 & -4340.93 \\
\hline
\end{tabular}

Notes: The first column shows which parameter $(\beta)$ from Models 1-4 is estimated. Estimates are standardized (see text for unstandardized estimates that are of greatest relevance). 95\% CIs are shown in brackets. $\sigma^{2}$ shows the within-subjects standard deviation. $\tau_{00}$ shows the between-subject standard deviation. ICC indicates the intra-class correlation, i.e., the proportion of variation between individuals $\left(\tau_{00}\right)$ explained by the overall variance $\left(\sigma^{2}+\tau_{00}\right)$. Marginal $\mathrm{R}^{2}$ provides the variance explained only by fixed effects and conditional $\mathrm{R}^{2}$ provides the variance explained by the entire model, i.e., both fixed effects and random effects. See Electronic Supplementary Material 1 for more details on variables (section 'Measures'). ${ }^{*} p<0.05,{ }^{* *} p<0.01, * * * p<0.001$.

\section{Robustness tests}

To test whether the observed effects are in favor of the null we used Bayes factors. We ran Model 2 with target families' origin using the package brms and bayestestR (Bürkner, 2018; Makowski et al., 2019), setting our priors for all fixed effects to $\sim N(\mu=0, \sigma=10)$ assuming that there is no effect with a broad distribution, which makes the prior weakly informative (keeping flat priors would not allow to compute the Bayes factor). We observed a small positive effect of daughters for males, $b=1.02,95 \% C I[-0.56,2.64]$, the likelihood that the effect is zero is $p(\mathrm{MAP})=.47$ (see Electronic Supplementary Material 1 Table S8). To compute the Bayes Factor, we had to define a null hypothesis by setting a null region, such that an effect that falls within this interval would be practically equivalent to the null (Kruschke, 2010). To compute all Bayes factors we deemed an effect in the range of $[-0.1,0.1]$ to be practically equivalent to the null. BFO1 indicates that the null hypothesis is 5.75 times more likely than the alternative hypothesis.

As a robustness test, we compared responses of people with no children, one daughter, or one son. The results (see Electronic Supplementary Material 1 Table S6) did not differ from the primary analyses. When treating having daughters as a binary variable (i.e., any daughters vs. no daughters), we find a nonsignificant effect for males when giving to a domestic family, $b=$ $1.99,95 \% C I[-0.71,4.70], p=.15$. For females giving to a domestic family, the effect was significantly more negative indicated by the interaction, $b=-3.86,95 \% C I[-7.03,-0.70], p=$ .03 , suggesting that for female participants the effect of daughters is different from males. Using 
a Bayesian approach to test the effect of parenting daughters on men shows, $b=-0.12,95 \% C I$ $[-1.57,1.32], p(\mathrm{MAP})=.99$. Due to the larger uncertainty about the size of the effect, $B F 01=$ 1.35 shows that the data does not yield conclusive evidence for the null or the alternative directed hypothesis (see Electronic Supplementary Material 1 Table S9).

Treating the number of daughters as an ordered categorical predictor relaxes the assumption of a constant linear effect. Simultaneously, it compares men without daughters to men with daughters without aggregation, which causes a loss of data. Once again, we did not find evidence in favor of a daughter effect, $b=1.89,95 \% C I[-0.45,5.92], p(\mathrm{MAP})=.491$. $B F 01=$ 3.62 provides evidence for the null compared to the alternative hypothesis (see Electronic Supplementary Material 1 Table S10).

All in all, we conclude that - for males - the null effect of parenting daughters is robust. See Electronic Supplementary Material 2 for notes on the origin of the recipient and the hurdle model.

\section{Discussion}

Parenting daughters is assumed to increase prosocial behavior in men, as they adopt preferences more similar to those exhibited by women. While Cronqvist and Yu (2017) show that parenting daughters increases corporate social responsibility - indicative of greater concern for the social good - our findings do not suggest that parenting daughters increases charitable giving in a Dictator Game. Thus, our findings point to a boundary in the universe of "daughter effects". We should note that we are not the first to report a null daughter effect: null effects were also reported for the relationship between parenting daughters and political orientation (Lee \& Conley, 2016), or the willingness to work for a morally controversial company (Niszczota \& Białek, 2021). This highlights the need for a theory that would explain why parenting daughters affects some behaviors, such as voting on women's rights issues (Washington, 2008), engagement in corporate social responsibility by CEOs (Cronqvist \& Yu, 2017), and the likelihood of hiring a female venture capital partner (Calder-Wang \& Gompers, 2021), but does not extend to monetary prosocial behavior, as exemplified by charitable giving.

There are some limitations to our study. Firstly, there may be differences in the daughter effect between the general population and the upper echelons of managers or politicians (e.g., CEOs and congressmen; Cronqvist \& Yu, 2017; Washington, 2008). Secondly, the recipient in the Dictator Game used here was a deserving household. While this is advantageous in eliciting social preferences - as it creates a circumstance, where a donation produces a relatively strong monetary effect (Engel, 2011) - generosity might be different in alternative scenarios (e.g., Walkowitz, 2021). Thirdly, it is plausible that men (and women) with more prosocial tendencies self-select into being parents, limiting our ability to accurately estimate the effect of parenthood on prosociality. At the same time, it is worth pointing out that our data does not support such self-selection happening, as men without children contribute similarly to men with children.

Finally, finding no difference in prosocial behavior in the Dictator Game of males with daughters could be due to an effect opposing higher prosociality when becoming a parent. Parenthood might increase pressure to ensure a higher income, making it easier not to behave prosocially, at least if doing so comes at a monetary cost. Some work suggests that parenthood leads to the adoption of more traditional gender roles in parents, increasing adherence to the male breadwinner, female homemaker model (Spain \& Bianchi, 1996). Further support for the notion that men might increase adherence to the male breadwinner, female homemaker model is provided by Dahl et al. (2012), who find that after fathering a child, male CEOs pay their employees less generously and pay themselves more, especially after fathering a son. 


\section{Electronic Supplementary Material}

ESM 1. Materials and supplementary items (.pdf)

Materials include instructions for the donation task (sourced from SOEP). Supplementary items are tables and figures corresponding to robustness and power tests.

ESM 2. Notes on alternative analytical approach and origin of the recipient (.pdf)

Notes concern the use of an alternative analytical approach (the hurdle model) and the origin of the recipient (domestic or foreign).

\section{References}

Achtziger, A., Alós-Ferrer, C., \& Wagner, A. K. (2015). Money, depletion, and prosociality in the dictator game. Journal of Neuroscience, Psychology, and Economics, 8(1), 1-14. https://doi.org/10.1037/npe0000031

Bilén, D., Dreber, A., \& Johannesson, M. (2020). Are Women More Generous Than Men? A Meta-Analysis (SSRN Scholarly Paper ID 3578038). Social Science Research Network. https://doi.org/10.2139/ssrn.3578038

Bürkner, P.-C. (2018). Advanced Bayesian Multilevel Modeling with the R Package brms. The R Journal, 10(1), 395-411.

Calder-Wang, S., \& Gompers, P. A. (2021). And the children shall lead: Gender diversity and performance in venture capital. Journal of Financial Economics, 142(1), 1-22. https://doi.org/10.1016/j.jfineco.2020.06.026

Cronqvist, H., \& Yu, F. (2017). Shaped by their daughters: Executives, female socialization, and corporate social responsibility. Journal of Financial Economics, 126(3), 543-562. https://doi.org/10.1016/j.jfineco.2017.09.003

Dahl, M. S., Dezső, C. L., \& Ross, D. G. (2012). Fatherhood and Managerial Style: How a Male CEO's Children Affect the Wages of His Employees. Administrative Science Quarterly, 57(4), 669-693. https://doi.org/10.1177/0001839212466521

Dittrich, M., \& Mey, B. (2021). Giving time or giving money? On the relationship between charitable contributions. Journal of Economic Psychology, 85, 102396. https://doi.org/10.1016/j.joep.2021.102396

Engel, C. (2011). Dictator games: A meta study. Experimental Economics, 14(4), 583-610. https://doi.org/10.1007/s10683-011-9283-7

Goebel, J., Liebig, S., Richter, D., Schröder, C., Schupp, J., \& Wenzig, K. (2018). SOEP Innovation Sample (SOEP-IS), data from 1998-2018. https://doi.org/10.5684/soep.is.2018

Ioannidis, J. P. A. (2005). Why Most Published Research Findings Are False. PLoS Medicine, 2(8). https://doi.org/10.1371/journal.pmed.0020124

Kruschke, J. K. (2010). What to believe: Bayesian methods for data analysis. Trends in Cognitive Sciences, 14(7), 293-300. https://doi.org/10.1016/j.tics.2010.05.001

Lee, B., \& Conley, D. (2016). Does the Gender of Offspring Affect Parental Political Orientation? Social Forces, 94(3), 1103-1127. https://doi.org/10.1093/sf/sov098

Makowski, D., Ben-Shachar, M. S., \& Lüdecke, D. (2019). bayestestR: Describing Effects and their Uncertainty, Existence and Significance within the Bayesian Framework. Journal of Open Source Software, 4(40), 1541. https://doi.org/10.21105/joss.01541

Niszczota, P., \& Białek, M. (2021). The effect of gender and parenting daughters on judgments of morally controversial companies. PLOS ONE, 16(12), e0260503. https://doi.org/10.1371/journal.pone.0260503

Spain, D., \& Bianchi, S. (1996). Balancing Act: Motherhood, Marriage, and Employment Among American Women. Russell Sage Foundation. 
Van Effenterre, C. (2020). Papa does preach: Daughters and polarization of attitudes toward abortion. Journal of Economic Behavior \& Organization, 179, 188-201. https://doi.org/10.1016/j.jebo.2020.08.049

Wagner, G. G., Frick, J. R., \& Schupp, J. (2007). The German Socio-Economic Panel Study (SOEP): Scope, Evolution and Enhancements (No. 1). DIW Berlin, The German Socio-Economic Panel (SOEP). https://ideas.repec.org/p/diw/diwsop/diw_sp1.html

Walkowitz, G. (2021). Dictator game variants with probabilistic (and cost-saving) payoffs: A systematic test. Journal of Economic Psychology, 85, 102387. https://doi.org/10.1016/j.joep.2021.102387

Warner, R. L. (1991). Does the Sex of Your Children Matter? Support for Feminism among Women and Men in the United States and Canada. Journal of Marriage and Family, 53(4), 1051-1056. https://doi.org/10.2307/353008

Washington, E. L. (2008). Female Socialization: How Daughters Affect Their Legislator Fathers. American Economic Review, 98(1), 311-332.

https://doi.org/10.1257/aer.98.1.311 


\section{Electronic Supplementary Materials 1}

\section{Measures}

\section{Donation (UE72 Experiment, SOEP-IS, Goebel et al., 2018)}

General instructions. Now, we would like to give you two tasks with which you could earn money again. In the two tasks, you have to decide whether to split a certain amount of money between another household and you or not. At the end, every 7th participant will be selected and their decision in one of the two tasks will be paid out. Whether your decision will be paid out is determined at the end of the module. The actual payment will occur at the end of the interview.

Domestic recipient. You were paired with another household in Germany who is also a participant in the innovation sample "Leben in Deutschland" but is not taking part in this interview. This household belongs to the poorest 10 percent of households in Germany. Now, you have 50 EUR at your disposal and can split this amount between the other household and you in any way you want. If this task is selected for payout, you will receive the amount you decided to keep at the end of the interview. The amount you want to give the other household will be given in full to the other household (without transaction costs) at the end of the field period by Kantar Public. In full means that every given euro will be received by the other household 1:1. I ask you to make this decision alone now.

How much of the 50 EUR do you want to keep and how much do you want to give the other household?

I keep EUR ... [1] and give EUR [2] to the other household.

Foreign recipient. You were paired with another household in Kenya or Uganda. This household belongs to the poorest 10 percent of households worldwide. Now, you have 50 EUR at your disposal and can split this amount between the other household and you in any way you want. If this task is selected for payout, you will receive the amount you decided to keep at the end of the interview. The amount you want to give the other household will be given in full to the other household (without transaction costs) at the end of the field period by Heidelberg University via a charitable organization. In full means that every given euro will be received by the other household 1:1. A leaflet with information about the donations will be given to you after you have made your decision. I ask you to make this decision alone now.

How much of the 50 EUR do you want to keep and how much do you want to give the other household?

I keep EUR ... [1] and give EUR [2] to the other household.

\section{Independent variables}

Number of daughters/Number of children. The number and sex of children were determined based on the birth data provided by the SOEP for each participant.

Female participant $(1=$ female, $0=$ male $)$. Biological sex codes of each participant in the SOEP as "male" or "female" were used.

Married $(\boldsymbol{I}=\boldsymbol{y} \boldsymbol{e s ,}, \boldsymbol{0}=\boldsymbol{n o})$. Marital status was determined based on SOEP-data from the 2017 wave.

Income. Income corresponds to monthly net income (in EUR) and was measured using self-reports responding to the question about their monthly net income from work, including overtime pay, but excluding vacation or back pay in the 2017 wave. The imputed values were provided by the SOEP (for 
the imputation process see Frick \& Grapka, 2014). As the distribution was right-skewed, we logtransformed values.

Age. Age was measured based on participants' date of birth as reported in the SOEP. To compute age in years, we subtracted the year of birth from the year of the data collection period.

Education. Education corresponds to years of education. This variable was computed and provided by the SOEP, taking years of schooling, professional training, and university education into account.

Catholic/Protestant/Other religion $(1=y e s, 0=n o)$. Religion was obtained from the life course data provided by the SOEP, but only entries from the year of the 2017 wave were used. 


\section{$\underline{\text { Tables }}$}

Table S2. Descriptive statistics.

Overall $(N=1,461)$

\section{Sex}

Female

$805(55.1 \%)$

Male

$656(44.9 \%)$

Age in years

Mean

54.016

SD

18.836

Median

56.000

Q1, Q3

$40.000,69.000$

\section{Religion}

N-Miss

853

Catholic

$174(28.6 \%)$

Islamic Religion

$4(0.7 \%)$

Member of an Islamic religious community

$4(0.7 \%)$

Member of another Christian denomination or religious community

$10(1.6 \%)$

Member of another religious community

$5(0.8 \%)$

No

$92(15.1 \%)$

Non-Denominational

$106(17.4 \%)$

Other Christian Religious Organization

$13(2.1 \%)$

Protestant

$200(32.9 \%)$

\section{Marital status}

N-Miss

1

Single

$338(23.2 \%)$

Divorced

$178(12.2 \%)$

Married

$766(52.5 \%)$

Married, But Separated

$36(2.5 \%)$

Registered same sex partnership

$4(0.3 \%)$

Widowed

$138(9.5 \%)$

\section{Net household income in $€$}

Mean 


\section{Overall $(N=1,461)$}

\begin{tabular}{ll}
\hline Median & 2700.000 \\
Q1, Q3 & $1700.000,3800.000$ \\
Number of biological daughters & \\
Mean & 0.771 \\
SD & 0.900 \\
Median & 1.000 \\
Q1, Q3 & $0.000,1.000$ \\
Number of biological sons & \\
Mean & 0.687 \\
SD & 0.834 \\
Median & 0.000 \\
Q1, Q3 & $0.000,1.000$ \\
Number of biological children & \\
Mean & 1.458 \\
SD & 1.236 \\
Median & 2.000 \\
Q1, Q3 & $0.000,2.000$ \\
Years of education & \\
Mean & 12.380 \\
SD & 2.723 \\
Median & 11.500 \\
Q1, Q3 & $10.500,14.000$ \\
\hline
\end{tabular}




\section{Table S3. Correlations between key variables}

\begin{tabular}{|c|c|c|c|c|c|c|}
\hline Variable & 1 & 2 & 3 & 4 & 5 & 6 \\
\hline 1. Age & & & & & & \\
\hline 2. Income & $\begin{array}{l}-.22 * * \\
{[-.27,-.17]}\end{array}$ & & & & & \\
\hline 3. Married & $\begin{array}{c}.21 * * \\
{[.16, .26]}\end{array}$ & $\begin{array}{c}.29 * * \\
{[.24, .34]}\end{array}$ & & & & \\
\hline 4. Years of education & $\begin{array}{l}-.04 \\
{[-.10, .01]}\end{array}$ & $\begin{array}{c}.34 * * \\
{[.29, .38]}\end{array}$ & $\begin{array}{l}.06^{*} \\
{[.01, .11]}\end{array}$ & & & \\
\hline 5. Number of biological daughters & $\begin{array}{c}.24 * * \\
{[.19, .29]}\end{array}$ & $\begin{array}{c}.03 \\
{[-.03, .08]}\end{array}$ & $\begin{array}{c}.25 * * \\
{[.20, .29]}\end{array}$ & $\begin{array}{l}-.08 * * \\
{[-.13,-.03]}\end{array}$ & & \\
\hline 6. Number of biological children & $\begin{array}{l}.36 * * \\
{[.32, .41]}\end{array}$ & $\begin{array}{c}.01 \\
{[-.04, .07]}\end{array}$ & $\begin{array}{c}.31 * * \\
{[.27, .36]}\end{array}$ & $\begin{array}{l}-.10 * * \\
{[-.16,-.05]}\end{array}$ & $\begin{array}{c}.74 * * \\
{[.71, .76]}\end{array}$ & \\
\hline 7. Proportion of endowment donated & $\begin{array}{l}-.07 * * \\
{[-.12,-.02]}\end{array}$ & $\begin{array}{c}.21 * * \\
{[.16, .26]}\end{array}$ & $\begin{array}{l}-.01 \\
{[-.06, .04]}\end{array}$ & $\begin{array}{c}.24 * * \\
{[.19, .29]}\end{array}$ & $\begin{array}{l}-.04 \\
{[-.09, .01]}\end{array}$ & $\begin{array}{l}-.05 \\
{[-.10, .00]}\end{array}$ \\
\hline
\end{tabular}

Notes: Values in square brackets indicate the $95 \%$ CIs for each correlation. $* p<0.05, * * p<0.01$ 
Table S4. The number of daughters, sons and children that participants had.

\begin{tabular}{lccc}
\hline & Count & Frequency & Relative frequency \\
\hline Number of daughters & 0 & 701 & 0.48 \\
1 & 472 & 0.32 \\
2 & 221 & 0.15 \\
3 & 56 & 0.04 \\
Number of sons & 4 & 8 & 0.01 \\
& $>4$ & 2 & 0.00 \\
& 0 & 738 & 0.51 \\
& 1 & 495 & 0.34 \\
& 2 & 186 & 0.13 \\
Number of children & 3 & 30 & 0.02 \\
& 4 & 9 & 0.01 \\
& $>4$ & 2 & 0.00 \\
& 0 & 431 & 0.30 \\
& 1 & 291 & 0.20 \\
& 2 & 485 & 0.33 \\
3 & 173 & 0.12 \\
& 4 & 57 & 0.04 \\
& & 23 & 0.02 \\
\hline
\end{tabular}


Table S5. Results of linear regression models predicting generosity, with standardized coefficients without experimental treatment factor recipient family origin.

\begin{tabular}{|c|c|c|c|c|}
\hline & Model 1 & Model 2 & Model 3 & Model 4 \\
\hline Intercept & $\begin{array}{c}0.00 \\
{[-0.05,0.05]}\end{array}$ & $\begin{array}{c}-0.09^{*} \\
{[-0.16,-0.02]}\end{array}$ & $\begin{array}{c}-0.10^{* *} \\
{[-0.17,-0.03]}\end{array}$ & $\begin{array}{c}-0.19 \\
{[-0.40,0.01]}\end{array}$ \\
\hline Number of daughters & $\begin{array}{c}0.02 \\
{[-0.05,0.09]}\end{array}$ & $\begin{array}{c}0.06 \\
{[-0.03,0.15]}\end{array}$ & $\begin{array}{c}0.01 \\
{[-0.08,0.10]}\end{array}$ & $\begin{array}{c}-0.02 \\
{[-0.18,0.14]}\end{array}$ \\
\hline Number of children & $\begin{array}{c}-0.07^{*} \\
{[-0.14,-0.00]}\end{array}$ & $\begin{array}{c}-0.08^{*} \\
{[-0.15,-0.01]}\end{array}$ & $\begin{array}{c}-0.04 \\
{[-0.11,0.03]}\end{array}$ & $\begin{array}{c}0.02 \\
{[-0.10,0.14]}\end{array}$ \\
\hline Female respondent & & $\begin{array}{c}0.16^{* * *} \\
{[0.07,0.26]}\end{array}$ & $\begin{array}{c}0.18^{* * *} \\
{[0.09,0.28]}\end{array}$ & $\begin{array}{c}0.29^{* * *} \\
{[0.14,0.44]}\end{array}$ \\
\hline $\begin{array}{l}\text { Number of daughters } \times \\
\text { Female respondent }\end{array}$ & & $\begin{array}{c}-0.06 \\
{[-0.15,0.04]}\end{array}$ & $\begin{array}{c}0.01 \\
{[-0.09,0.10]}\end{array}$ & $\begin{array}{c}-0.01 \\
{[-0.17,0.15]}\end{array}$ \\
\hline Married & & & $\begin{array}{c}-0.08^{* *} \\
{[-0.13,-0.02]}\end{array}$ & $\begin{array}{c}-0.08 \\
{[-0.16,0.01]}\end{array}$ \\
\hline Income & & & $\begin{array}{c}0.20^{* * *} \\
{[0.15,0.26]}\end{array}$ & $\begin{array}{c}0.16^{* * *} \\
{[0.07,0.25]}\end{array}$ \\
\hline Education & & & $\begin{array}{c}0.17^{* * *} \\
{[0.12,0.23]}\end{array}$ & $\begin{array}{c}0.22^{* * *} \\
{[0.14,0.31]}\end{array}$ \\
\hline Age & & & $\begin{array}{c}-0.02 \\
{[-0.07,0.03]}\end{array}$ & $\begin{array}{c}-0.03 \\
{[-0.11,0.06]}\end{array}$ \\
\hline Religion $=$ Catholic & & & & $\begin{array}{c}0.14 \\
{[-0.10,0.38]}\end{array}$ \\
\hline Religion $=$ Protestant & & & & $\begin{array}{c}0.02 \\
{[-0.21,0.26]}\end{array}$ \\
\hline Religion $=$ Other & & & & $\begin{array}{c}-0.05 \\
{[-0.30,0.20]}\end{array}$ \\
\hline \multicolumn{5}{|l|}{ Random Effects } \\
\hline$\sigma^{2}$ & 0.03 & 0.03 & 0.03 & 0.03 \\
\hline$\tau_{00}$ & 0.07 pid & 0.07 pid & 0.06 pid & 0.06 pid \\
\hline $\mathrm{ICC}$ & 0.71 & 0.71 & 0.69 & 0.71 \\
\hline $\mathrm{N}$ & 1460 pid & 1460 pid & 1368 pid & 559 pid \\
\hline Observations & 2918 & 2918 & 2734 & 1116 \\
\hline Marginal $\mathrm{R}^{2}$ / Conditional $\mathrm{R}^{2}$ & $0.003 / 0.715$ & $0.011 / 0.715$ & $0.098 / 0.720$ & $0.119 / 0.740$ \\
\hline Deviance & 392.564 & 379.654 & 168.227 & 48.141 \\
\hline $\mathrm{AICc}$ & 425.858 & 429.876 & 261.590 & 154.947 \\
\hline log-Likelihood & -207.919 & -207.919 & -119.747 & -63.283 \\
\hline
\end{tabular}


Notes: $95 \%$ CIs are shown in brackets. $\sigma^{2}$ shows the within-subjects standard deviation. $\tau_{00}$ shows the between-subject standard deviation. ICC indicates the intra-class correlation, i.e., the proportion of variation between individuals $\left(\tau_{00}\right)$ explained by the overall variance $\left(\sigma^{2}+\tau_{00}\right)$. Marginal $R^{2}$ provides the variance explained only by fixed effects and conditional $\mathrm{R}^{2}$ provides the variance explained by the entire model, i.e., both fixed effects and random effects.

$* p<0.05, * * p<0.01, * * * p<0.001$. 
Table S6. Results of hurdle regression models predicting generosity without experimental treatment factor recipient family origin.

\begin{tabular}{|c|c|c|c|c|}
\hline & Model 1 & Model 2 & Model 3 & Model 4 \\
\hline \multicolumn{5}{|c|}{ Beta regression (conditional model) } \\
\hline Intercept & $\begin{array}{c}-0.41^{* * *} \\
{[-0.54,-0.27]}\end{array}$ & $\begin{array}{c}-0.55^{* * *} \\
{[-0.73,-0.36]}\end{array}$ & $\begin{array}{c}-0.46^{* * *} \\
{[-0.68,-0.25]}\end{array}$ & $\begin{array}{c}-0.83^{* * *} \\
{[-1.29,-0.37]}\end{array}$ \\
\hline Precision & 2.15 & 2.15 & 2.17 & 2.15 \\
\hline Number of daughters & $\begin{array}{c}0.11 \\
{[-0.03,0.25]}\end{array}$ & $\begin{array}{c}0.13 \\
{[-0.05,0.31]}\end{array}$ & $\begin{array}{c}0.09 \\
{[-0.08,0.27]}\end{array}$ & $\begin{array}{c}0.03 \\
{[-0.30,0.36]}\end{array}$ \\
\hline Number of children & $\begin{array}{c}-0.18^{* * *} \\
{[-0.28,-0.07]}\end{array}$ & $\begin{array}{c}-0.19^{* * *} \\
{[-0.29,-0.09]}\end{array}$ & $\begin{array}{c}-0.15^{* *} \\
{[-0.26,-0.04]}\end{array}$ & $\begin{array}{c}-0.11 \\
{[-0.28,0.06]}\end{array}$ \\
\hline Female respondent & & $\begin{array}{c}0.25^{*} \\
{[0.03,0.48]}\end{array}$ & $\begin{array}{c}0.27^{*} \\
{[0.04,0.49]}\end{array}$ & $\begin{array}{c}0.52^{* *} \\
{[0.20,0.85]}\end{array}$ \\
\hline $\begin{array}{l}\text { Number of daughters } \times \\
\text { Female respondent }\end{array}$ & & $\begin{array}{c}-0.03 \\
{[-0.22,0.16]}\end{array}$ & $\begin{array}{c}0.01 \\
{[-0.18,0.20]}\end{array}$ & $\begin{array}{c}0.04 \\
{[-0.29,0.37]}\end{array}$ \\
\hline Married & & & $\begin{array}{c}-0.06 \\
{[-0.26,0.14]}\end{array}$ & $\begin{array}{c}0.07 \\
{[-0.23,0.38]}\end{array}$ \\
\hline Income & & & $\begin{array}{c}0.87^{* * *} \\
{[0.44,1.31]}\end{array}$ & $\begin{array}{c}0.84^{* *} \\
{[0.21,1.47]}\end{array}$ \\
\hline Education & & & $\begin{array}{c}0.08^{* * *} \\
{[0.04,0.11]}\end{array}$ & $\begin{array}{c}0.07^{*} \\
{[0.02,0.12]}\end{array}$ \\
\hline Age & & & $\begin{array}{c}-0.00 \\
{[-0.01,0.00]}\end{array}$ & $\begin{array}{c}-0.01 \\
{[-0.01,0.00]}\end{array}$ \\
\hline Religion $=$ Catholic & & & & $\begin{array}{c}0.33 \\
{[-0.10,0.75]}\end{array}$ \\
\hline Religion $=$ Protestant & & & & $\begin{array}{c}0.16 \\
{[-0.26,0.57]}\end{array}$ \\
\hline Religion $=$ Other & & & & $\begin{array}{c}-0.09 \\
{[-0.53,0.36]}\end{array}$ \\
\hline
\end{tabular}

Logistic regression (hurdle model predicting non-perfect altruism)

$\begin{array}{lcccc}\text { (Intercept) } & 8.03^{* * *} & 8.26^{* * *} & 7.87^{* * *} & 7.41^{* * *} \\ & {[7.29,8.77]} & {[7.35,9.18]} & {[6.74,9.00]} & {[5.04,9.78]} \\ \text { Number of daughters } & 0.06 & -0.09 & 0.03 & 0.10 \\ & {[-0.52,0.63]} & {[-0.81,0.63]} & {[-0.76,0.82]} & {[-1.36,1.56]} \\ \text { Number of children } & -0.03 & -0.02 & -0.08 & -0.29 \\ & {[-0.44,0.38]} & {[-0.43,0.40]} & {[-0.56,0.40]} & {[-1.06,0.49]}\end{array}$


Notes: 95\% CIs are shown in brackets. The conditional model was fitted using a beta regression for proportional data reflecting the degree of generosity. The estimates are under a logit-link function. The intercept shows the alpha and the precision the beta parameter. The hurdle model was fitted using a binomial regression (logistic) predicting keeping some (0) vs. keeping nothing (1). The estimates are under a logit-link function. $\sigma^{2}$ shows the within-subjects standard deviation. $\tau_{00}$ shows the betweensubject standard deviation. ICC indicates the intra-class correlation, i.e. the proportion of variation between individuals $\left(\tau_{00}\right)$ explained by the overall variance $\left(\sigma^{2}+\tau_{00}\right)$. Marginal $\mathrm{R}^{2}$ provides the variance explained only by fixed effects and conditional $\mathrm{R}^{2}$ provides the variance explained by the entire model, i.e., both fixed effects and random effects.

$* p<0.05,{ }^{* *} p<0.01, * * * p<0.001$. 
Table S7. Results of linear and hurdle regression models: subset of people that either had no children or one child without experimental treatment factor recipient family origin.

\begin{tabular}{|c|c|c|}
\hline & Linear & Hurdle \\
\hline & & $\begin{array}{c}\text { Beta regression } \\
\text { (conditional model) }\end{array}$ \\
\hline Intercept & $\begin{array}{c}0.59^{* * *} \\
{[0.55,0.63]}\end{array}$ & $\begin{array}{c}-0.35^{* *} \\
{[-0.59,-0.11]}\end{array}$ \\
\hline Precision & & -2.26 \\
\hline One daughter & $\begin{array}{c}0.01 \\
{[-0.07,0.09]}\end{array}$ & $\begin{array}{c}-0.15 \\
{[-0.60,0.30]}\end{array}$ \\
\hline One son & $\begin{array}{c}-0.01 \\
{[-0.08,0.07]}\end{array}$ & $\begin{array}{c}0.10 \\
{[-0.34,0.54]}\end{array}$ \\
\hline Female respondent & $\begin{array}{c}0.07^{*} \\
{[0.01,0.12]}\end{array}$ & $\begin{array}{c}0.40^{*} \\
{[0.09,0.71]}\end{array}$ \\
\hline Married & $\begin{array}{c}-0.04 \\
{[-0.09,0.01]}\end{array}$ & $\begin{array}{c}0.01 \\
{[-0.27,0.30]}\end{array}$ \\
\hline Income & $\begin{array}{c}0.18^{* * *} \\
{[0.09,0.28]}\end{array}$ & $\begin{array}{c}0.56 \\
{[-0.00,1.12]}\end{array}$ \\
\hline Education & $\begin{array}{c}0.02^{* * *} \\
{[0.01,0.03]}\end{array}$ & $\begin{array}{c}0.10^{* * *} \\
{[0.06,0.15]}\end{array}$ \\
\hline Age & $\begin{array}{c}-0.00 \\
{[-0.00,0.00]}\end{array}$ & $\begin{array}{c}-0.01{ }^{*} \\
{[-0.01,-0.00]}\end{array}$ \\
\hline One daughter $\times$ Female respondent & $\begin{array}{c}-0.02 \\
{[-0.12,0.09]}\end{array}$ & $\begin{array}{c}-0.10 \\
{[-0.70,0.50]}\end{array}$ \\
\hline \multirow[t]{2}{*}{ One son $\times$ Female respondent } & $\begin{array}{c}0.00 \\
(-0.11,0.10)\end{array}$ & $\begin{array}{c}-0.02 \\
{[-0.62,0.57]}\end{array}$ \\
\hline & & $\begin{array}{c}\text { Logistic regression } \\
\text { (hurdle model } \\
\text { predicting non- } \\
\text { perfect altruism) }\end{array}$ \\
\hline Intercept & & $\begin{array}{c}7.86^{* * *} \\
{[6.49,9.24]}\end{array}$ \\
\hline One daughter & & $\begin{array}{c}-0.30 \\
{[-2.36,1.77]}\end{array}$ \\
\hline One son & & $\begin{array}{c}0.37 \\
{[-1.80,2.53]}\end{array}$ \\
\hline
\end{tabular}


Notes: $95 \%$ CIs are shown in brackets. In the hurdle model, the conditional model was fitted using a beta regression for proportional data reflecting the degree of generosity. The estimates are under a logit-link function. The first hurdle was fitted using a binomial regression (logistic) predicting keeping some (0) vs. keeping nothing (1). The estimates are under a logit-link function. $\sigma^{2}$ shows the withinsubjects standard deviation. $\tau_{00}$ shows the between-subject standard deviation. ICC indicates the intraclass correlation, i.e. the proportion of variation between individuals $\left(\tau_{00}\right)$ explained by the overall variance $\left(\sigma^{2}+\tau_{00}\right)$. Marginal $\mathrm{R}^{2}$ provides the variance explained only by fixed effects and conditional $\mathrm{R}^{2}$ provides the variance explained by the entire model, i.e., both fixed effects and random effects. $* p$ $<0.05, * * p<0.01, * * * p<0.001$. 
Table S8. Standardized regression models predicting generosity accounting for the experimental treatment factor recipient family origin.

\begin{tabular}{|c|c|c|}
\hline & Linear Model & Hurdle Model \\
\hline & & $\begin{array}{c}\text { Beta regression } \\
\text { (conditional model) }\end{array}$ \\
\hline Intercept & $\begin{array}{c}-0.20^{* * *} \\
{[-0.28,-0.13]}\end{array}$ & $\begin{array}{c}-0.54^{* * *} \\
{[-0.76,-0.31]}\end{array}$ \\
\hline Precision & & -2.20 \\
\hline Number of daughters & $\begin{array}{c}0.01 \\
{[-0.08,0.11]}\end{array}$ & $\begin{array}{c}0.09 \\
{[-0.10,0.27]}\end{array}$ \\
\hline Female respondent & $\begin{array}{c}0.16^{* *} \\
{[0.06,0.27]}\end{array}$ & $\begin{array}{c}0.27^{*} \\
{[0.03,0.51]}\end{array}$ \\
\hline Foreign recipient & $\begin{array}{c}0.21^{* * *} \\
{[0.15,0.26]}\end{array}$ & $\begin{array}{c}0.15^{*} \\
{[0.03,0.27]}\end{array}$ \\
\hline Number of children & $\begin{array}{c}-0.04 \\
{[-0.11,0.03]}\end{array}$ & $\begin{array}{c}-0.15^{* *} \\
{[-0.26,-0.05]}\end{array}$ \\
\hline Married & $\begin{array}{c}-0.08^{* *} \\
{[-0.13,-0.02]}\end{array}$ & $\begin{array}{c}-0.06 \\
{[-0.260 .14]}\end{array}$ \\
\hline Income & $\begin{array}{c}0.20^{* * *} \\
{[0.15,0.26]}\end{array}$ & $\begin{array}{c}0.89^{* * *} \\
{[0.45,1.32]}\end{array}$ \\
\hline Education & $\begin{array}{c}0.17^{* * *} \\
{[0.12,0.23]}\end{array}$ & $\begin{array}{c}0.08^{* * *} \\
{[0.04,0.11]}\end{array}$ \\
\hline Age & $\begin{array}{c}-0.02 \\
{[-0.07,0.03]}\end{array}$ & $\begin{array}{c}-0.00 \\
{[-0.01,0.00]}\end{array}$ \\
\hline $\begin{array}{l}\text { Number of daughters } \times \\
\text { Female respondent }\end{array}$ & {$\left[\begin{array}{l}-0.02 \\
{[-0.12,0.08]}\end{array}\right.$} & $\begin{array}{c}-0.00 \\
{[-0.21,0.20]}\end{array}$ \\
\hline $\begin{array}{l}\text { Number of daughters } \times \\
\text { Foreign recipient }\end{array}$ & $\begin{array}{c}-0.01 \\
{[-0.07,0.05]}\end{array}$ & $\begin{array}{c}0.02 \\
{[-0.09,0.12,]}\end{array}$ \\
\hline $\begin{array}{l}\text { Female respondent } \times \text { Foreign } \\
\text { recipient }\end{array}$ & $\begin{array}{c}0.04 \\
{[-0.04,0.11]}\end{array}$ & $\begin{array}{c}0.00 \\
{[-0.17,0.17]}\end{array}$ \\
\hline \multirow[t]{2}{*}{$\begin{array}{l}\text { Number of daughters } \times \text { Female } \\
\text { respondent } \times \text { Foreign recipient }\end{array}$} & $\begin{array}{c}0.05 \\
{[-0.03,0.12]}\end{array}$ & $\begin{array}{c}0.04 \\
{[-0.10,0.19]}\end{array}$ \\
\hline & & $\begin{array}{c}\text { Logistic } \\
\text { regression } \\
\text { (hurdle model } \\
\text { predicting } \\
\text { non- perfect } \\
\text { altruism) }\end{array}$ \\
\hline
\end{tabular}


Intercept

Number of daughters

$-2.43^{* *}$

$[-4.10,-0.77]$

Female

$-0.61$

$[-2.70,1.48]$

Foreign recipient

$-10.05^{* * *}$

$[-8.59,-11.52]$

Number of children

$-0.03$

$[0.69,-0.75]$

Married

0.25

$[1.57,-1.06]$

Income

$-2.12$

$[0.88,-5.13]$

Education

$-0.16$

[0.06, -0.37]

Age

$-0.00$

$[0.03,-0.04]$

Number of daughters $\times$ Female $2.91^{* *}$

respondent

$[4.83,0.98]$

Number of daughters $x$

$2.56^{* * *}$

Foreign recipient

$[3.86,1.26]$

Female respondent $\times$ Foreign

0.22

recipient

$[1.86,-1.42]$

Number of daughters $\times$ Female

$-3.05^{* * *}$

respondent $\times$ Foreign recipient

$[-1.42,-4.68]$

\section{Random Effects}

$\sigma^{2}$

0.02

$-0.03$

$\tau_{00 \text { pid }}$

0.06

1.80

ICC

0.71

1.02

$\mathrm{N}_{\text {pid }}$

1368

1368

Observations

2734

2734 
Marginal $\mathrm{R}^{2}$ / Conditional $\mathrm{R}^{2}$

AICc

log-Likelihood
162.058
$0.090 / 1.014$

381.863

Notes: $95 \%$ CIs are shown in brackets. Linear model shows standardized $\beta$. The conditional model was fitted using a beta regression for proportional data reflecting the degree of generosity. The estimates are under a logit-link function. The intercept shows the alpha and the precision the beta parameter. The hurdle model was fitted using a binomial regression (logistic) predicting keeping some (0) vs. keeping nothing (1). The estimates are under a logit-link function. $\sigma^{2}$ shows the within-subjects standard deviation. $\tau_{00}$ shows the between-subject standard deviation. ICC indicates the intra-class correlation, i.e. the proportion of variation between individuals $\left(\tau_{00}\right)$ explained by the overall variance $\left(\sigma^{2}+\tau_{00}\right)$. Marginal $\mathrm{R}^{2}$ provides the variance explained only by fixed effects and conditional $\mathrm{R}^{2}$ provides the variance explained by the entire model, i.e., both fixed effects and random effects. $* p<0.05, * * p<0.01, * * * p<0.001$. 
Table S9. Bayesian Analysis for Model 2 predicting donation size.

Predictors

Intercept

27.55

$[25.96,29.14]$

Number of daughters (1)

1.02

$[-0.56,2.64]$

Female participant (2)

3.28

$[1.18,5.26]$

Foreign donation (3)

$[2.51,4.72]$

Number of children (4)

$-1.03$

$[-1.94,-0.17]$

$1 \times 2$

$-1.30$

$[-3.04,0.44]$

$-0.24$

$1 \times 3$

$[-1.18,0.70]$

0.03

$2 \times 3$

$[-1.45,1.57]$

$1 \times 2 \times 3$

0.66

$[-0.60,1.92]$

Random Effects

$\sigma^{2}$

61.62

$\tau_{00 \text { pid }}$

ICC

0.74

$\mathrm{N}_{\text {pid }}$

1460

Observations

2918

Marginal $\mathrm{R}^{2} /$ Conditional $\mathrm{R}^{2}$

$0.028 / 0.744$

Notes: $95 \%$ CIs are shown in brackets. $\sigma^{2}$ shows the within-subjects standard deviation. $\tau_{00}$ shows the between-subject standard deviation. ICC indicates the intra-class correlation, i.e. the proportion of variation between individuals $\left(\tau_{00}\right)$ explained by the overall variance $\left(\sigma^{2}+\tau_{00}\right)$. Marginal $R^{2}$ provides the variance explained only by fixed effects and conditional $\mathrm{R}^{2}$ provides the variance explained by the entire model, i.e., both fixed effects and random effects.

$* p<0.05,{ }^{* *} p<0.01, * * * p<0.001$. 
Table S10. Bayesian Analysis for Model 2 predicting donation size assuming a binary daughter predictor.

\begin{tabular}{|c|c|}
\hline Predictors & $B$ \\
\hline Intercept & $\begin{array}{c}28.56 \\
{[27.23,29.90]}\end{array}$ \\
\hline Has daughter $(=1$ yes, $=0$ no) (1) & $\begin{array}{c}-0.11 \\
{[-1.57,1.32]}\end{array}$ \\
\hline Female participant (2) & $\begin{array}{c}1.45 \\
{[0.18,2.77]}\end{array}$ \\
\hline Foreign donation (3) & $\begin{array}{c}2.89 \\
{[2.05,3.74]}\end{array}$ \\
\hline Number of children (4) & $\begin{array}{c}-0.66 \\
{[-1.35,0.03]}\end{array}$ \\
\hline $1 \times 2$ & $\begin{array}{c}-0.56 \\
{[-1.99,0.96]}\end{array}$ \\
\hline $1 \times 3$ & $\begin{array}{c}0.17 \\
{[-0.92,1.25]}\end{array}$ \\
\hline $2 \times 3$ & $\begin{array}{c}0.99 \\
{[-0.07,2.03]}\end{array}$ \\
\hline $1 \times 2 \times 3$ & $\begin{array}{c}0.02 \\
{[-1.28,1.26]}\end{array}$ \\
\hline \multicolumn{2}{|l|}{ Random Effects } \\
\hline$\sigma^{2}$ & 61.71 \\
\hline$\tau_{00 \text { pid }}$ & 172.79 \\
\hline ICC & 0.74 \\
\hline $\mathrm{N}_{\text {pid }}$ & 1460 \\
\hline Observations & 2918 \\
\hline Marginal $\mathrm{R}^{2}$ / Conditional $\mathrm{R}^{2}$ & $0.020 / 0.743$ \\
\hline
\end{tabular}

Notes: $95 \%$ CIs are shown in brackets. $\sigma^{2}$ shows the within-subjects standard deviation. $\tau_{00}$ shows the between-subject standard deviation. ICC indicates the intra-class correlation, i.e. the proportion of variation between individuals $\left(\tau_{00}\right)$ explained by the overall variance $\left(\sigma^{2}+\tau_{00}\right)$. Marginal $R^{2}$ provides the variance explained only by fixed effects and conditional $\mathrm{R}^{2}$ provides the variance explained by the entire model, i.e., both fixed effects and random effects.

$* p<0.05, * * p<0.01, * * * p<0.001$. 
Table S11. Bayesian Analysis for Model 2 predicting donation size assuming an ordered categorical daughter predictor.

\begin{tabular}{lc}
\hline Predictors & $\mathrm{B}$ \\
\hline Intercept & 27.58 \\
& {$[26.07,29.14]$} \\
Daughter (ordered cat.) (1) & 1.52 \\
& {$[-0.45,5.92]$} \\
Female participant (2) & 3.57 \\
& {$[1.35,5.69]$} \\
Foreign donation (3) & 3.55 \\
& {$[1.65,5.46]$} \\
Number of children (4) & -1.00 \\
& {$[-1.64,-0.34]$} \\
$1 \times 2$ & -1.24 \\
$1 \times 3$ & {$[-3.32,0.92]$} \\
& -0.26 \\
$2 \times 3$ & {$[-3.76,2.80]$} \\
& 0.17 \\
&
\end{tabular}

Monotonic Effects

simo_moordered_daughter1[1]

0.09

$[0.01,0.36]$

simo_moordered_daughter1[2]

0.06

$[0.00,0.35]$

simo_moordered_daughter1[3]

0.16

$[0.01,0.53]$

simo_moordered_daughter1[4]

0.08

$[0.00,0.42]$

simo_moordered_daughter1[5]

0.19

$[0.01,0.63]$

simo_moordered_daughter1[6]

0.23

$[0.01,0.69]$

simo_moordered_daughter:sexFemale1[1]

0.27

$[0.02,0.60]$ 


$$
\begin{aligned}
& \text { simo_moordered_daughter:sexFemale1[2] } \\
& 0.08 \\
& {[0.00,0.36]} \\
& \text { simo_moordered_daughter:sexFemale1[3] } \\
& 0.08 \\
& {[0.00,0.38]} \\
& \text { simo_moordered_daughter:sexFemale1[4] } \\
& 0.15 \\
& {[0.01,0.52]} \\
& 0.13 \\
& \text { simo_moordered_daughter:sexFemale1[5] } \\
& {[0.01,0.50]} \\
& 0.12 \\
& \text { simo_moordered_daughter:sexFemale1[6] } \\
& {[0.00,0.50]} \\
& 0.09 \\
& \text { simo_moordered_daughter:conditionforeign1[1] } \\
& {[0.00,0.41]} \\
& \text { simo_moordered_daughter:conditionforeign1[2] } \\
& 0.09 \\
& {[0.00,0.43]} \\
& 0.12 \\
& \text { simo_moordered_daughter:conditionforeign1[3] } \\
& {[0.00,0.50]} \\
& \text { simo_moordered_daughter:conditionforeign1[4] } \\
& 0.16 \\
& {[0.01,0.63]} \\
& 0.15 \\
& \text { simo_moordered_daughter:conditionforeign1[5] } \\
& {[0.01,0.56]} \\
& 0.15 \\
& {[0.01,0.59]} \\
& 0.08 \\
& \text { simo_moordered_daughter:sexFemale:conditionforeign1[1] } \\
& \text { simo_moordered_daughter:sexFemale:conditionforeign1[2] } \\
& \text { simo_moordered_daughter:sexFemale:conditionforeign1[3] } \\
& \text { simo_moordered_daughter:sexFemale:conditionforeign1[4] } \\
& \text { simo_moordered_daughter:sexFemale:conditionforeign1[5] } \\
& \text { simo_moordered_daughter:sexFemale:conditionforeign1[6] } \\
& {[0.00,0.44]} \\
& 0.12 \\
& {[0.00,0.47]} \\
& 0.14 \\
& {[0.01,0.51]} \\
& 0.12 \\
& {[0.00,0.51]} \\
& 0.15 \\
& {[0.01,0.56]} \\
& 0.17 \\
& {[0.01,0.61]}
\end{aligned}
$$




\section{Figures}

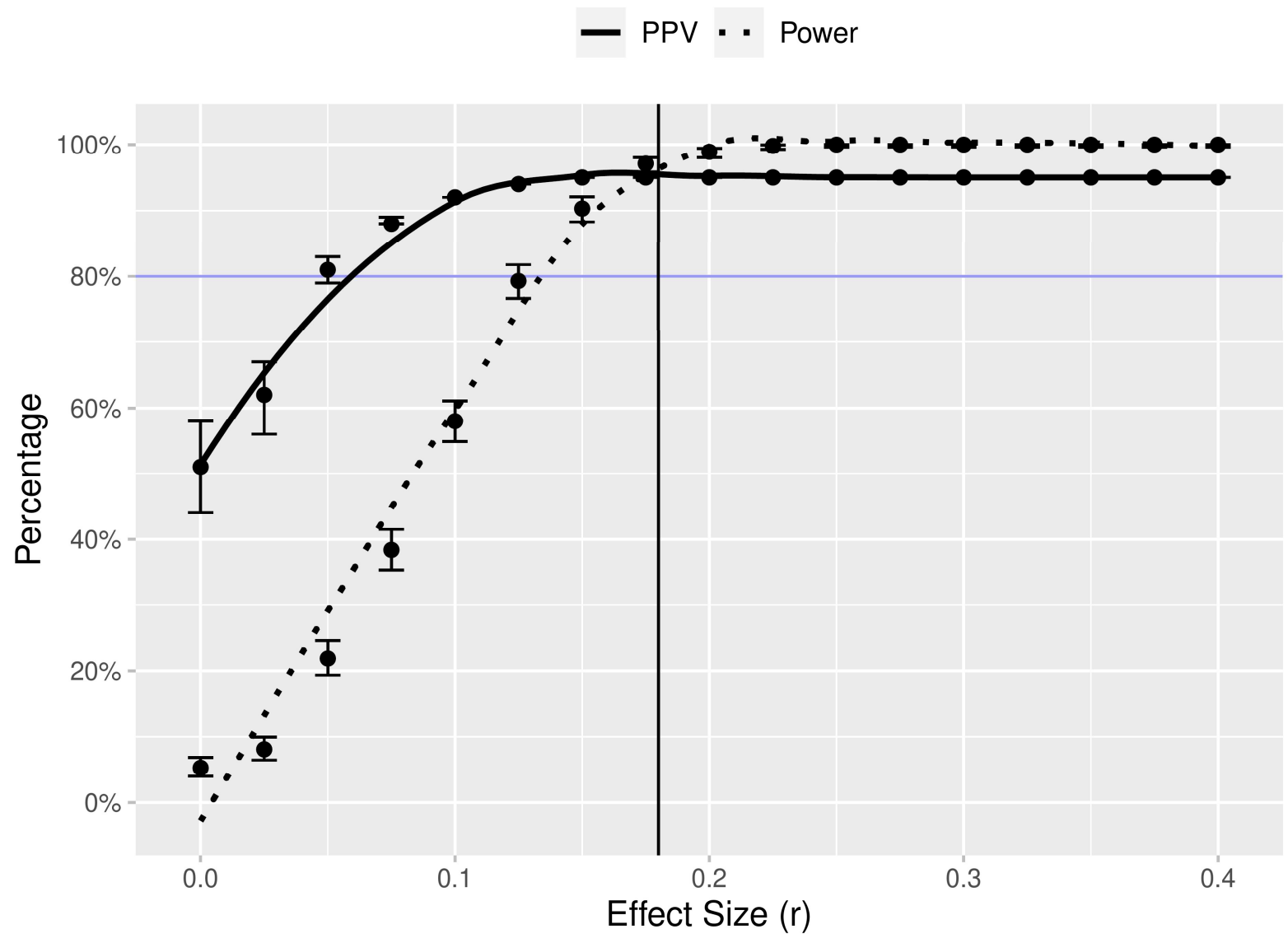

Fig. S1. Curve for the power and positive predictive values.

Notes: The horizontal blue line shows $80 \%$ power. The vertical black line shows the effect for being female. 

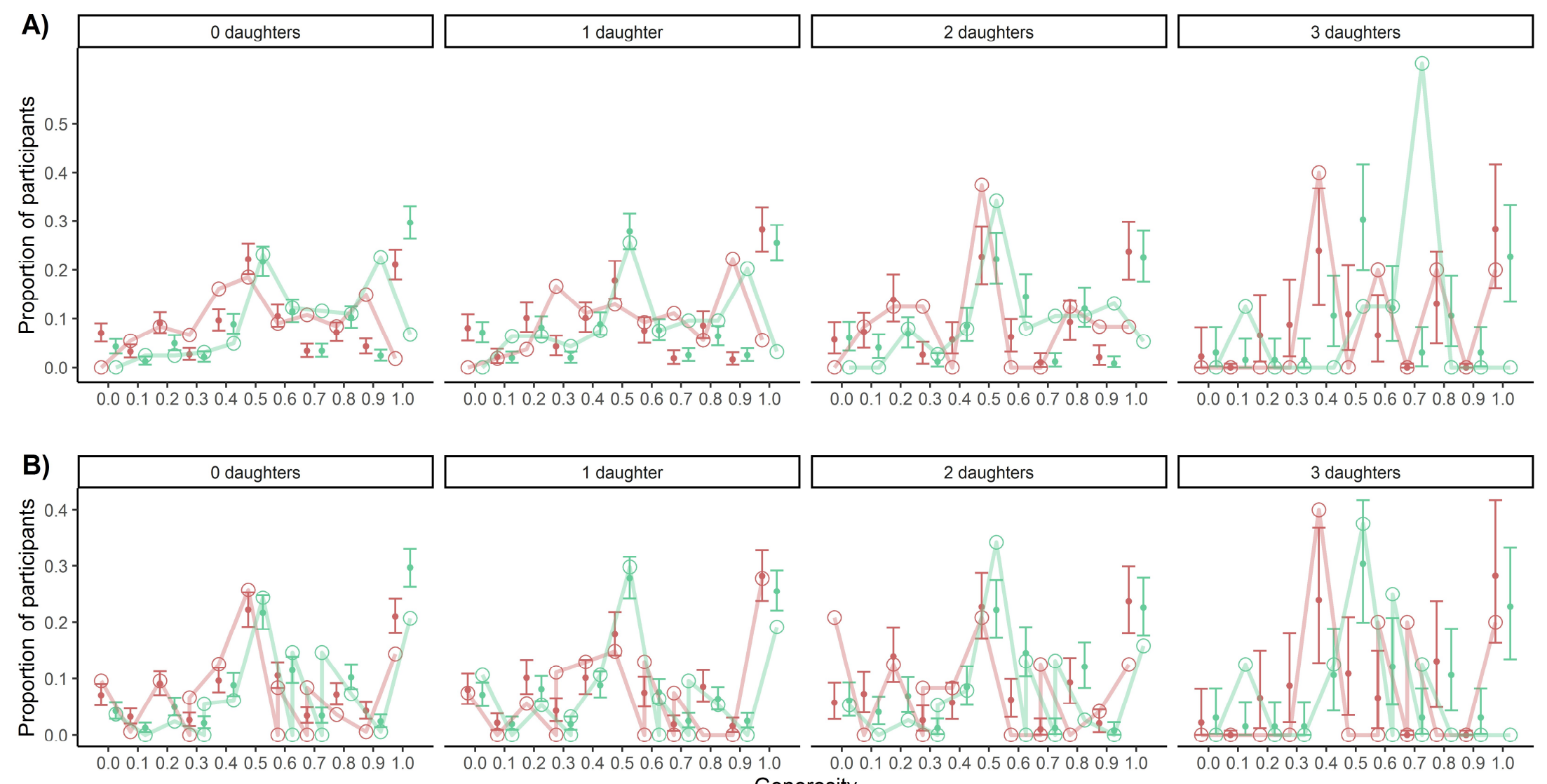

Generosity

Respondent sex $\rightarrow$ Male $\rightarrow$ Female

\section{Fig. S2. Observed and predicted selfishness depending on the number of daughters.}

Notes: The point and error bars show the observed proportion and 95\% CIs for each level of generosity. The line and open point show the predicted proportion from the model. Panel A shows predictions from the linear model. Panel B shows predictions from the hurdle model. 


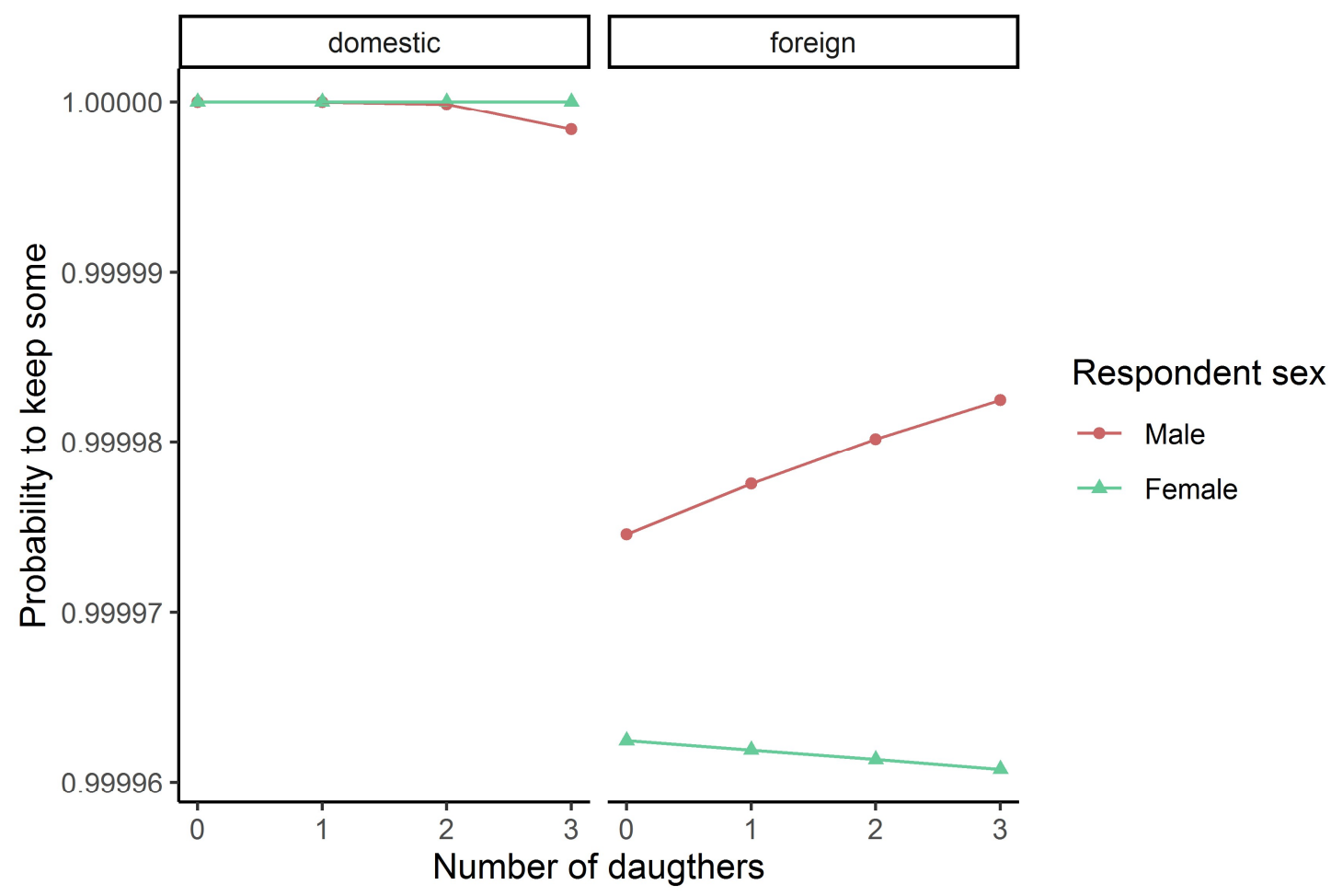

Fig. S3. Plotted prediction of the interaction of target origin $\times$ respondent $\operatorname{sex} \times$ number of daughters in the binomial part of the hurdle model. 


\section{Electronic Supplementary Materials 2}

\section{Hurdle model}

The distribution of the dependent variable in Dictator Games is often bimodal: the endowment has two peaks, one peak at zero (i.e., give nothing), and another peak at .5 (i.e., split 50:50; see Engel, 2011). For this reason, we additionally carried out a hurdle model, that first analyzed the binary decision to be perfectly generous or not with a binomial logit model, and then used linear regression with a $\beta$-distribution for the degree of generosity conditional on the decision to give something at all. For the hurdle model, we reversed the scale when fitting the model (from generous to selfish), as the hurdle model predicts 0 -values and not $1 \mathrm{~s}$ in the logistic part. This allowed the hurdle model analysis to split the responses into two unimodal distributions. We report the results of the hurdle model in Electronic Supplementary Material 1 Tables S5-S7.

In the hurdle model, we observed an interaction between the number of daughters and the origin-of-the-recipient. We show all regression model results in Electronic Supplementary Material 1 Tables S5-S7 and graphical predictive plots to ease interpretation of the hurdle model in Electronic Supplementary Material 1 Fig. S3. We must caution the reader that the likelihood of keeping some of the endowment is almost 1.00 or on the logit scale $\mathrm{OR}=20.64$ $[22.92,18.36]$ and the OR of all predictors must be interpreted always in relation to this intercept.

\section{Origin of recipient}

The SOEP IS donation decision contained an experimental factor. It was varied within subjects, whether the donation was to be to a domestic family belonging to the poorest $10 \%$ of the population to a foreign family belonging to the poorest $10 \%$ of the population in Uganda or Kenya. Implicit in the variation is the manipulation of need, as $10 \%$ of the poorest families in foreign countries are relatively worse off compared to domestic families.

We did not observe any interaction effect of the experimental factor in the linear regression. Having one daughter decreased the likelihood to keep some of the endowment in males when deciding to give to a domestic family, OR $=-2.43[-0.77,-4.10]$, but it increases the likelihood to keep the full endowment when deciding to give to a foreign family, $\mathrm{OR}=-2.56[1.26$, 2.86]. A significant Daughters $\times$ Female $\times$ Foreign donation interaction, $\mathrm{OR}=-3.05[-1.42,-$ 4.68], indicates that for females the number of daughters decreases the likelihood to keep the full endowment when deciding to give to a foreign family. 